\title{
ANALISIS KANDUNGAN ZAT GIZI DAN TOTAL UJI CEMARAN SUSU KAMBING PERANAKAN ETAWAH YANG DIKONSUMSI OLEH IBU HAMIL DAN ANAK - ANAK
}

\author{
Ratnasari Dewi*) \\ *) Jurusan Farmasi Poltekkes Kemenkes Makassar
}

\begin{abstract}
ABSTRAK
Telah dilakukan penelitian tentang Analisis Kandungan Zat Gizi Dan Total Uji Cemaran Susu Kambing Peranakan Etawah Yang Dikonsumsi Oleh Ibu Hamil Dan Anak - Anak. Penelitian ini bertujuan membantu pemerintah dalam hal diversifikasi pangan, menggalakkkan kegemaran minum susu kepada masyarakat luas, khususnya penduduk Indonesia dan memperkenalkan kepada khalayak ramai sumber zat gizi yang bisa dijadikan alternatif minuman yang bergizi selain susu sapi. Penelitian ini bertujuan untuk melihat kadar protein dan kalsium serta ada tidaknya bakteri aerob dan anaerob pada penentuan Angka Lempeng Total bakteri yang biasa terdapat pada Susu kambing Peranakan Etawah yang berasal dari Animal Center Fakultas Peternakan UNHAS di Makassar. Penelitian ini menggunakan metode analisis, cara penentuan protein dengan cara titrasi formol untuk menghidrolisis protein dalam sampel, penetapan kadar kalsium dengan memakai metode kompleksometri, penentuan angka lempeng total memakai metode tuang . Data yang telah diperoleh kemudian dianalisis dengan perhitungan kadar, baik kadar ptoteinnya maupun kadar kalsiumnya serta jumlah Angka Lempeng Total sampel susu, apakah layak dikonsumsi atau tidak berdasarkan hasil pemeriksaan yang diperoleh. Hasil yang diperoleh adalah untuk sampel susu kambing, Kadar protein rata - ratanya adalah 5,69 \%, untuk kadar kalsium dari sampel susu kambing PE adalah : 30,76\% dan pemeriksaan jumlah angka lempeng total diperoleh 0 koloni / ml. Dari hasil penelitian menunjukkan bahwa susu kambing peranakan etawah (PE) layak dikonsumsi oleh masyarakat, sebagai sumber gizi yang sangat diperlukan oleh tubuh.
\end{abstract}

Kata Kunci : Uji cemaran, susu kambing peranakan Etawah.

\section{PENDAHULUAN}

Dalam rangka memenuhi

kebutuhan dan perbaikan gizi bagi masyarakat Indonesia terutama protein, karbohidrat, lemak dan mineral, maka masyarakat Indonesia perlu mengetahui sumber - sumber gizi tersebut dalam makanan yang hendak dipilihnya, baik yang berasal dari hewan maupun tumbuhan.

Susu merupakan salah satu pangan sebagai sumber protein hewani, yang mengandung protein, lemak, mineral, kalsium, vitamin dan mengandung asam amino esensial yang lengkap.

Susu disebut sebagai bahan pangan yang hampir sempurna karena kandungan zat gizinya yang lengkap. Di Indonesia, hampir $90 \%$ kambing dipelihara untuk tujuan menghasilkan daging. Tentunya kenyataan ini sangat

Manfaat susu kambing sangatlah luar biasa, selain dapat membantu proses penyembuhan berbagai macam penyakit maupun perawatan tubuh serta menjaga stamina, susu kambing juga dapat membantu meningkatkan kemampuan reproduksi, menjaga tumbuh kembang janin, membantu proses persalinan normal, meningkatkan kualitas ASI, membantu organ pencernaan balita, meningkatkan berat badan serta daya tahan tubuh balita agar tahan terhadap perubahan cuaca maupun makanan yang mengandung pengawet, yang dapat memicu alergi pada balita.

Kambing perah yang banyak dikembangkan di Indonesia umumya kambing Peranakan Etawah yang menjadi salah satu ternak indigenous dan memiliki potensi genetik yang tinggi sebagai penghasil dwiguna (daging dan susu). Akan tetapi, masih lebih dominan sebagai sumber daging jika dibandingkan dengan sumber susu, karena susu kambing belum banyak dikonsumsi secara Iuas oleh masyarakat seperti susu sapi. Meskipun masyarakat Indonesia masih belum banyak mengonsumsi susu kambing, diduga alasan utama karena aroma dari susu kambing itu sendiri. Namun sebagian masyarakat yang beranggapan bahwa susu kambing dapat 
menyembuhkan berbagai macam penyakit, seperti; asma, TBC, alergi, dan kanker sudah mulai berpindah untuk lebih memilih mengonsumsi susu kambing. Walaupun belum terbukti secara ilmiah anggapan yang berkembang di sebagian masyarakat tersebut, namun diduga ada satu polipeptida aktif yang menjadikan susu kambing berkhasiat dan dapat digunakan sebagai terapi penyakit-penyakit tersebut

\section{METODE DAN BAHAN \\ Jenis Penelitian}

Penelitian ini merupakan penelitian eksperimen laboratorium secara in vitro.

\section{Waktu Penelitian}

Penelitian ini dilakukan pada bulan Mei sampai Oktober 2017. Makassar.

\section{Tempat Penelitian}

Dilaksanakan di Laboratorium

Kimia Jurusan Farmasi Politeknik

Kesehatan Kementerian Kesehatan

\section{Bahan Penelitian}

Bahan-bahan yang digunakan dalam penelitian ini adalah; Susu cair, Aquades, Tablet Kejdhall, $\mathrm{NaOH} 50 \%$, Asam borat 20\%, Indikator BGG (Brom Gresol Green), HCL 0.02 N (untuk penetapan kadar protein), dan untuk penetapan kadar kalsium digunakan; Sampel susu kambing Peranakan Ettawa, Aquades, $\mathrm{NaOH} 1 \mathrm{M}$, Indikator Boruhidroksi Naftol (BHN), EDTA 0,05 M, Larutan baku CaCO3 0,05 M. Untuk menentukan angka lempeng total bakteri digunakan; Pereaksi, Triphenyl Tetrazolium Chloride 0,5\% (TCC)

\section{Penyiapan sampel}

Sampel susu kambing Peranakan Etawah diambil dari tempat pemeliharaan kambing Animal Centre, Fakultas Peternakan Universitas Hasanuddin, Makassar.

\section{Penentuan kadar protein}

Mengambil \pm 2 gr sampel , ditambahkan 1 biji tablet Kejdhall dan $10 \mathrm{ml}$ $\mathrm{H} 2 \mathrm{SO} 4$, kemudian di dekstruksi selama 40 menit, setelah itu didinginkan lalu didestilasi dengan menambahkan aquades $20 \mathrm{ml}$ dan 50 $\mathrm{ml} \mathrm{NaOH} 50 \%$.

\section{Penentuan kadar kalsium}

Mula-mula ditimbang sampel sebanyak 1 gram ke dalam Erlenmeyer secara saksama atau ukur 15,0 cuplikan susu cair, kemudian ditambahkan $10 \mathrm{ml}$ aquades dan 25,0 $\mathrm{ml}$ larutan EDTA 0,05 $\mathrm{M}$, setelah itu ditambahkan $15 \mathrm{ml}$ larutan $\mathrm{NaOH} 1 \mathrm{M}$ sampai bereaksi alkalis dan 200 $\mathrm{mg}$ indikator biru hidroksi naftol (BHN), dan titrasi dengan larutan baku $\mathrm{CaCO} 30,05$ $M$ dengan pengocokan yang konstan sampai terjadi pewarnaan ungu. Lakukan percobaan blanko. Hitung kandungan kalsium dengan rumus :

Kadar $\mathrm{Ca}=\frac{(\text { V blanko }-\mathrm{V} \text { sampel }) \times \mathrm{M} \text { CaCO3 } \times 40}{\text { Berat sampel }(\mathrm{ml})}$

\section{Penentuan Angka Lempeng Total Bakteri} (ALT)

Penentuan ALT ialah dengan cara aseptic ditimbang $25 \mathrm{gr}$ atau dipipet $25 \mathrm{ml}$ ke dalam kantong stomacher steril, lalu ditambahkan $225 \mathrm{ml}$ PDF, dihomogenkan dengan stomacher selama 30 detik, sehingga diperoleh suspensi dengan pengenceran ${ }^{10-1}$ atau sesuai dengan MA no. 60/ MIK/00, disiapkan 5 tabung atau lebih yang masing - masing telah di isi dengan 9 ml PDF. Hasil dari homogenisasi pada penyiapan sampel yang merupakan pengenceran ${ }^{10-1}$. Dipipet sebanyak $1 \mathrm{ml}$ ke dalam tabung PDF pertama, dikocok homogen hingga diperoleh pengenceran ${ }^{10-}$ 2 . Dibuat pengenceran selanjutnya hingga 10-6 atau sesuai dengan pengenceran yang diperlukan. Dari setiap pengenceran dipipet $1 \mathrm{ml}$ ke dalam cawan petri dan di buat duplo. Ke dalam setiap cawan petri dituangkan $15-20 \mathrm{~mL}$ media PCA - $1 \%$ TTC suhu $\pm 45{ }^{\circ} \mathrm{C}$, cawan petri segera digoyang dan diputar sedemikian rupa hingga suspense tersebar merata. Untuk mengetahui sterilitas media dan pengencer dalam control (Blanko). Pada satu cawan diisi $1 \mathrm{~mL}$ pengencer dan media agar, dan pada cawan yang lain diisi media. Setelah media memadat, cawan diinkubasi pada suhu $35-37{ }^{\circ} \mathrm{C}$ selama 24 - 48 jam dengan posisi dibalik. Jumlah koloni yang tumbuh diamati dan dihitung.

\section{Penetapan Kadar Protein dan Mineral (Kalsium) Serta Penentuan Angka Lempeng Total (ALT) \\ Untuk penetapan kadar protein dengan menggunakan rumus :}


$\%$ Kadar Protein $=$

Volume HCL sampel - Volume HCL Blanko X N

HCL X 0.014 X fp X fk Berat sampel X $100 \%$

Untuk penetapan kadar kalsium dalam susu :

Kadar $\mathrm{Ca}=$

(Volume Blanko - Volume sampel ) X M CaCO3 X 40 Berat sampel (mL)

\section{Cara Pengumpulan Data}

Data yang diperoleh merupakan data primer, hasil pehitungan dengan menggunakan rumus yang sudah ditetapkan.

\section{Analisis Data}

Data yang sudah diperoleh kemudian diolah dan dibandingkan dengan literatur serta hasil - hasil penelitian selanjutnya.

\section{HASIL DAN PEMBAHASAN \\ Hasil Penelitian}

Kadar protein susu kambing PE berkisar antara 3,4 sampai 9,9\% dengan rata - rata 5,69\%. Hal ini sesuai dengan persyaratan mutu protein minimal Standar Nasional Indonesia (SNI) dalam susu adalah 2,7\%. (BSN, 1998)

Tabel. 1. Kadar Protein

\begin{tabular}{cccc}
\hline Sampel Susu & Kambing PE A & Kambing PE B & Kambing PE C \\
\hline I & $3,69 \%$ & $3,50 \%$ & $9,91 \%$ \\
II & $3,66 \%$ & $3,44 \%$ & $10,06 \%$ \\
III & $3,67 \%$ & $3.50 \%$ & $8,84 \%$ \\
\hline Kadar rata-rata & $3,67 \%$ & $3,48 \%$ & $9,60 \%$ \\
\hline
\end{tabular}

Sumber : Data primer 2017

Hasil yang diperoleh pada penelitian yang dilakukan oleh Ratih Rara dan Rachman Rony juga tidak jauh berbeda yaitu sekitar 3,3\% / $100 \mathrm{ml}$. Komposisi susu dan produksi kambing PE ini dipengaruhi oleh banyak faktor, diantaranya sistem manajemen (pengelolaan) yang dipakai, jumlah dan jenis pakan yang diberikan, manajemen kesehatan dan iklim tempat kambing tersebut dipelihara. Di samping itu, produksi dan komposisi susu juga sangat dipengaruhi oleh masa laktasi, periode laktasi dan manajemen sistem pemberian pakan.

Rataan kandungan protein susu adalah $4,57 \%$. Hasil ini sedikit lebih tingi dari peneliti lain yang mendapatkan kadar protein susu pada kambing PE sebesar 3,9\% (Subaghiana, 2010), sebesar 3,3\% (Eldstein, 2011) kondisi ini diduga karena dalam proses sistesis susu di control di dalam kelejar ambing (Schenist, 1998). Secara umum produksi susu kambing sangat dipengaruhi oleh kualitas pakan yang diberikan, dimana sebagian besar precursor untuk sintesis air susu dalam kelenjar ambing berasal dari darah yang sangat bergantung pada kualitas pakan dan proses penyerapan di dalam tubuh. Sudah dibuktikan bahwa pakan yan berkualitas memberikan nutrient darah yang lebih tinggi dan berkorelasi terhadap proses sintesis susu di dalam sel sekretoris kelenjar ambing yang akhirnya meningkatkan produksi dan kualitas susu yang dihasilkan. (Jurnal ilmiah ilmu - ilmu peternakan volume XVII No 1, mei 2014).

Dalam tabel 1 juga ada nilai tertinggi kadar protein, yaitu kambing $\mathrm{PE}$ dengan kode $\mathrm{C}$, hal ini karena kambing ini masih memiliki kolustrum pada saat pengambilan sampel, dimana kolustrum diketahui memang paling banyak mengandung protein. Komposisi kandungan bahan pada kolustrum sangat kaya dan padat, hal ini disebabkan karena kolustrum mengandung kadar protein, (Adu \& Ngere, 2012), melaporkan kandungan protein pada susu kolustrum mengandung lebih dari $20 \%$ yaitu $4-5$ kali lebih tinggi dari kandungan protein setelah masa tersebut. Komposisi susu sangat dipengaruhi oleh periode laktasi. (Sutama dan Budiarsana, 2010) 
Tabel. 2. Kadar Kalsium

\begin{tabular}{cccc}
\hline Sampel susu & Kambing PE A & Kambing PE B & Kambing PE C \\
\hline 1 & $3,06 \%$ & $3,06 \%$ & $2,66 \%$ \\
2 & $3,09 \%$ & $3,16 \%$ & $2,18 \%$ \\
\hline Kadar rata - rata & $3,075 \%$ & $4,64 \%$ & $2,42 \%$ \\
\hline
\end{tabular}

Sumber : Data primer 2017

Susu kambing merupakan salah satu sumber kalsium, beratnya sekitar $129 \mathrm{mg}$. Sedangkan kebutuhan kalsium bagi manusia sekitar 800 - $1000 \mathrm{mg}$ perhari. Sementara itu wanita hamil kebutuhan kalsiumnya lebih banyak, sekitar $150 \mathrm{mg}$ perhari dibandingkan dengan wanita normal. Kalsium dalam tubuh menunjang pembentukan tulang dan gigi. Jika wanita hamil kekurangan kalsium diambil cadanagn kalsium pada tulang sehingga tulang keropos atau osteoporosis.

Dari tabel 2 menunjukkan kadar rata - rata kalsium dari sekitar 2,26 sampai 3,06 mg. Dalam beberapa literatur yang menghitung dalam persen diperoleh $0,18 \%$, seperti diketahui bersama bahwa susu kambing PE ini sangat kaya akan kalsium dan asam amino triptofan. Kalsium yang terdapat dalam susu kambing PE sangat bermanfaat untuk pertumbuhan tulang dan gigi (bagi balita), serta dapat mencegah osteoporosis (pengeroposan tulang) dan pengapuran tulang yang umumnya diderita oleh orang tua dan lansia.

Hasil penelitian dari Lembaga Penelitian Dan Pengabdian Pada Masyarakat IPB, mendapatkan kadar kalsium per 100 ml susu kambing PE sekitar $130 \mathrm{mg}$, hasil yang diperoleh ini menguatkan beberapa hasil penelitian yang mengatakan bahwa kandungan kalsium susu kambing PE jauh lebih tinggi dibandingkan dengan susu sapi bahkan ASI sekalipun. Susu kambing juga telah disadari sebagai sumber gizi (protein) tinggi dan dapat dinikmati secara langsung oleh masyarakat serta dapat menyembuhkan berbagai macam penyakit seperti gangguan pencernaan dan paru - paru.

Ada banyak faktor yang

mempengaruhi produksi dan komposisi susu kambing, diantaranya :

1. Variasi antar jenis kambing,

Dengan aneka karakteristik yang berbeda satu dangan lainnya maka akan terdapat variasi dalam jumlah produksi susunya.

2. Variasi inter jenis kambing Setiap individu dan jenis/bangsa yang sama memiliki variasi dalam jumlah susu yang dihasilkan walaupun jenis atau bangsa sama, tetapi jika umur dan masa laktasi berbeda maka jumlah produksi susu juga berbeda.

3. Faktor genetik

Adalah faktor yang diturunkan dari nenek moyang dan memiiki sifat kebakaan.

4. Musim

Hasil penelitian menunjukkan bahwa kambing yang beranakpada musim gugur memiliki tingkat produksi yang lebih tinggi disbanding kambing yang beranak pada musim panas

5. Umur

Produksi susu kambing meningkat seiring bertambahya umur dan mencapai uncak pada saat berumur 5 - 7 tahun, yakni pada masa laktasi ke 3 atau ke 5 selanjutnya prodksi susu akan menurun

6. Lama masa laktasi

Dalam satu jenis atau bangsa kambing perbedaan masa laktasi menyebabkan perbedaan jumlah total produksi susu selama masa laktasi. Semakin lama masa laktasi akan semakin banyak total produksi susu yang dihasilkan. Korelsi ini tidak berarti akan semakin tinggi keuntungan yang diraih

7. Faktor perawatan dan perlakuan

Suasana kandang yang nyaman sangat mendukung untuk berproduksi secara optimal

8. Pengaruh masa birahi dan kebuntingan

Kambing yang dikawinkan kembali setelah 3 bulan beranak, tingkat produksi susunya akan lebih cepat menurun dibanding kambing yang 
sedang laktasi tetapi tidak bunting. Hal ini mugkinkan disebabkan kurangnya kuantitas dan kualitas pakan yang dikonsumsi, serta tinginya kebutuhan kambing akan zat - zat makanan untuk mendukung proses fisiologis dalam tubuhnya.

9. Frekuensi Pemerahan

Berdasar hasil penelitian kambing yang diperah $2 \times$ sehari total produksi susunya lebih tinggi dari pada kambing yang diperah 1 x sehari

10. Jumlah anak dalam sekali melahirkan

Produksi susu kambing perah yang beranak 2 ekor dalam 1 kali melahirkanbiasanya $20-30 \%$ lebih tinggi dari kambing perah yang hanya beranak 1 ekor. Penyebabnya adalah rangsangan menyusui dari anak kambing (cempe) yang dilahirkan

11. Pergantian pemerah

Kambing termasuk hewan yang tidak terlalu mudah beradaptasi pada kondisi lingkungan yang berubah drastic. Pergantian pemerah akan menyebabkan kambing mengalami stress.

12. Lama masa kering

Untuk mendorong produksi beranak 3 kali dalam 2 tahun biasanya kambing dikawinkan kembali setelah beranak 3 bulanatau saat pertama birahi muncul. Dalam kondisi demikian kambing membutuhkan waktu untuk menjalani masa kering selama 2 bulan agar memiliki kesempatan untuk kembali pulih kondisinya.

13. Faktor hormonal

Hormon yang berperan dalam produksi susu adalah laktogen. Penyuntikan hormon ini pada saat laktasi menyebabkan produks susu meningkat

14. Faktor pakan

Produksi susu akan mencapai optimal jika pakan yang diberikan dan dikonsumsi oleh kambing, jumlah dan kualitasnya cukup. Komposisi hijauan dan konsntrat harus seimbang

15. Pengaruh penyakit

Kambing perah yang sedang laktasi produksi susunya akan menurun jika terserang penyakit, bahkan bisa langsung terhenti. Efek obat yang diberikan juga akan berpengaruh terhadap produksi dan kualitas susu yang dihasilkan. (Danu Kusuma, 2014)

Tabel. 3 Pemeriksaan ALT (Angka Lempeng Total)

\begin{tabular}{cc}
\hline Sampel susu & Kambing PE A \\
\hline 1 & 0 \\
\hline Sumber : Data primer 2017 \\
Angka Lempeng & Total (ALT)
\end{tabular}
adalah jumlah koloni yang tumbuh pada media dari pengenceran sampel. Hal ini dikarenakan dengan melakukan pengenceran, maka jumlah mikroba yang tersuspensi di dalam air steril menjadi lebih kecil. Uji ALT digunakan untuk menghitung banyaknya bakteri yang tumbuh dan berkembang pada sampel, juga sebagai acuan yang dapat menentukan kualitas dan keamanan susu kambing PE. Pada pemeriksaan susu kambing PE ini, hasil yang didapatkan adalah 0 koloni/gram. Ketiga sampel yang didperiksa semuanya tidak memiliki pertumbuhan bakteri, yang berarti susu kambing PE aman dikonsumsi dalam bentuk segar. Standar khusus untuk susu kambing saat ini belum tersedia, tetapi persyratan susu segar dapat mengacu pada SNI No. 7388- 2009. Berdasarkan SNI No, Kambing PE B Kambing PE C

$0 \quad 0$

7388 - 2009 maka persyaratan susu segar mempunyai TPC dan koliform masing masing $1 \times 10^{6} \mathrm{cfu} / \mathrm{ml}, 2 \times 10^{6} \mathrm{cfu} / \mathrm{ml}$, sedangkan $E$. coli adalah negatif (Hijriah Firbarama Pione, 2016 ). Sebagai produk pangan yang kaya nutrisi, susu memiliki kandungan $\mathrm{pH}$ yang mendekati netral dan kandungan airnya tinggi. Oleh karena itu susu sangat mudah mengalami kerusakan akibat pencemaran mikroba.

\section{PENUTUP}

\section{Kesimpulan}

Dari hasil penelitian yang telah dilakukan, maka dapat diambil beberapa kesimpulan, bahwa memelihara kambing peranakan etawah (PE) sebagai kambing dwiguna (untuk produksi daging dan susu) masih mempunyai potensi untuk dikembangkan. Produksi susunya berpotensi untuk memperbaiki gizi masyarakat, juga 
dapat menyembuhkan penyakit. Hasil kadar protein rata - rata dan kadar kalsium adalah $5,69 \%$ dan 2,26 - 3,06 mg, sedangkan penentuan angka lempeng total (ALT) diperoleh nilai 0 koloni/mg. Susu kambing PE yang telah diperiksa dinyatakan dapat dikonsumsi dengan aman sebagai minuman yang bergizi tinggi.

\section{DAFTAR PUSTAKA}

Anonim, 2008, Protein Susu, Http :// Queen Of Sheeba. Word Press.Com,. 17 $09-2012$

Budiarsana I.G.M. dan Sutama I.K., Efisiensi Produksi susu kambing Pernakan Etawah., Seminar Nasional Teknologi Peternakan dan Veteriner, 2010

Cholissodin Imam,Sutrisno, Soebroto,Hanum Latifah, CaesarAmerillyse Canny, Optimasi Kandungan Gizi Susu Kambing PE menggunakan ELM - PSO di UPT Pembibitan Ternak Dan Hijauan Makanan Ternak Singosari Malang, Jurnal Teknologi Informasi dan Ilmu Komputer (JTIIK), vol. 4 no 1 Maret 2017 hal. $31-36$

Hijriah firbarama pione, skripsi., Status mikrobiologi susu kambing Pernaakan Etawa (PE) di Desa Sungai Langka Kecamatan Gedong Tataan Kabupaten Pesawaran., 2016

I.A.M. Sukarini, Produksi dan Komposisi Air Susu Kambing peranakan Etawa (PE) Yang Diberi Tambahan Konsentrat Pada Awal Laktasi, Jurusan produksi Ternak, Fakultas Peternakan, Universitas Udayana, Denpasar, Jurnal 2015

Kusuma Danu, Analisa usaha Kambing etawa dan susu kambing etawa, 2014, Jakarta, penebar swadana

Majalah Kesehatan. Com / Kandungan dan Manfaat Susu Kambing, 2011

Mulyanto, Damayanti, Rini \& $\mathrm{T}$, Bernardinus, Wiryanto, Wahyu, Gramedia. Sehat Dengan Ramuan Tradisional Dan Manfaat Susu
Kambing , Susu Terbaik Dari Hewan Ruminansia

Niswah, Fathun. 2012. Pemanfaatan susu Kambing Etawa Dan Kedelai Dalam Pembuatan Dangke Keju Khas Indonesia Dengan Koagulan Ekstrak Jeruk Nipis . ( Skripsi )

Ratih Rara dan Rachman Ronny, LPPMIPB, Warga Iptek, Perbandingan Kandungan nutrisi Asi, Susu Sapi Dan Susu Kambing, 2012

Sarwono, B. 2011. Beternak Kambing Unggul. Jakarta : Penebar Swadaya

Sastrohamidjojo, Hardjono. 2015. Kimia Organik, Yogyakarta : Gadjah Mada University Press.

Susilorini, Tri Eko. 2013. Produk Olahan Susu. Jakarta

Winarno . 2013. Kimia Pangan Dan Gizi. Jakarta : PT. Gramaedia Pustaka.

Zakaria, Yusdar., dkk Analisa Kualitas susu Kambing Peranakan Etawah Yang Disterilkan Pada Suhu Dan Waktu Yang Berbeda. Agripet Vol.11, No 1, April 2011 